\title{
DESAIN AGROFORESTRY PADA LAHAN KRITIS (STUDI KASUS DI KECAMATAN INDRAPURI KABUPATEN ACEH BESAR)
}

\author{
Design of Agroforestry in Critical Land: Case Study in Indrapuri Subdistrict, Aceh Besar District \\ Bukhari dan Indra Gumay Febryano
}

\begin{abstract}
Design of agroforestry has the objectives of improving the system which has been existing and providing directives for agribusiness on the basis of physical, economical, and socio-cultural condition. Design of a system is inevitably related with pre-diagnosis and diagnosis activities which are aimed at discovering the existing constraints and problems inside the system, followed by technological intervention for system improvement and determining the best agroforestry system in critical land condition. Method used in this study was identifying the existing agroforestry system, followed by evaluation of land suitability, financial analysis and community social analysis. This study found three agroforestry systems based on the existing components, namely agrisilviculture, silvopasture, and agrisilvopasture. Evaluation of land suitability showed that in general, land suitability ratings for woody crops and perennial crops were categorized as moderately suitable (S2), while those for annual crops / non rice food crops were categorized as marginally suitable (S3). Results of financial analysis showed that all existing agroforestry system are feasible to be practiced, with highest benefit cost ratio 2.7 was found in agrisilvopasture system. On the basis of landscape consideration, species of Non-MPTs were more adapted if they were planted in hill ridge, while that of species of MPTs and perennial crops in slope and valley, and that of annual crops in valley.
\end{abstract}

Key words: agroforestry, land suitability, critical land, design

\section{PENDAHULUAN}

Usaha-usaha pertanian tradisional yang dilakukan dengan mengkonversi lahan hutan menjadi lahan pertanian, sering menjadi penyebab terjadinya lahan kritis. Di Indonesia praktek-praktek usaha tani dan pemanfaatan lahan yang tidak atau kurang memperhatikan kaidah-kaidah konservasi tanah dan air, serta praktek perladangan berpindah menyebabkan timbulnya lahan kritis, erosi, bencana kekeringan, serta penurunan kualitas dan kuantitas hasil pertanian. Statistik Departemen Kehutanan dan Perkebunan (2002), menyebutkan bahwa Provinsi Nanggroe Aceh Darussalam memiliki luas lahan kritis mencapai 860.659,93 ha, yang digolongkan dalam tingkat sangat kritis seluas 5.777 ha, kritis 320.248 ha, agak kritis $96.738,29$ ha, dan potensial kritis 437.896,51 ha. Sementara berdasarkan data BPS Aceh Besar (2006), Kabupaten Aceh Besar memiliki luas lahan kritis mencapai 31.319 ha.

Produktivitas lahan dapat ditingkatkan melalui perbaikan sifat fisik tanah (lapisan atas) yang paling penting dan dibutuhkan untuk menunjang pertumbuhan berbagai jenis tanaman dan pepohonan adalah struktur dan porositas tanah, kemampuan menahan air dan laju infiltrasi. Lapisan atas tanah merupakan tempat yang mewadahi berbagai proses dan kegiatan kimia, fisik dan biologi yakni organisme makro dan mikro termasuk perakaran tanaman dan pepohonan. Sistem agroforestri dapat mempertahankan sifatsifat fisik lapisan tanah atas yang diperlukan untuk menunjang pertumbuhan tanaman (Widianto et al, 2003). Meningkatnya intensifikasi pertanian akan mengubah kondisi tanah suatu agroekosistem sehingga menyebabkan hilangnya biodiversitas organisme tanah. Hal tersebut disebabkan oleh adanya penurunan jumlah dan diversitas masukan organik ke dalam rantai makanannya, dan adanya penggunaan bahan kimia serta modifikasi iklim mikro (Van Noordwijk dan Hairiah, 2006).

Agroforestri adalah nama kolektif untuk sistem-sistem dan teknologi-teknologi penggunaan lahan, yang secara terencana dilaksanakan pada satu unit lahan dengan mengkombinasikan tumbuhan berkayu (pohon, perdu, palem, bambu dll.) dengan tanaman pertanian dan/atau hewan 
(ternak) dan/atau ikan, yang dilakukan pada waktu yang bersamaan atau bergiliran sehingga terbentuk interaksi ekologis dan ekonomis antar berbagai komponen yang ada (Lundgren dan Raintree, 1982). Sistem agroforestri memiliki perpaduan antara berbagai jenis tanaman, sehingga perlu diketahui potensi lahan atau kelas/kemampuan lahan untuk tipe penggunaan lahan (jenis tanaman dan tingkat pengelolaan) tertentu (Harjowigeno dan Widiatmaka, 2001). Untuk itulah diperlukan suatu desain yang merupakan proses merumuskan, secara spasial dan temporal penggunaan lahan dan melihat kemungkinan terbaik dari segi ekonomi, lingkungan dan sosial (Wojtkowski, 2002).

Berdasarkan permasalahan tersebut diatas, dilakukan suatu penelitian yang bertujuan untuk menyusun suatu desain agroforestri pada lahan kritis berdasarkan potensi kesesuaian lahan, sistem agroforestri dan jenis tanaman yang direkomendasikan, serta aspek sosial ekonominya. Hasil penelitian ini diharapkan bermanfaat sebagai informasi bagi para petani dan penentu kebijakan dalam menetapkan pola usaha tani yang dapat meningkatkan pendapatan petani dan produktivitas pertanian. Selain itu dapat menjadi masukan bagi penentu kebijakan di dalam perencanaaan pengelolaan lahan kritis dengan menerapkan sistem agroforestri.

\section{BAHAN DAN METODE}

\section{Lokasi dan Waktu}

Penelitian dilaksanakan di Kecamatan Indrapuri, Kabupaten Aceh Besar, Provinsi Nanggroe Aceh Darussalam, pada bulan Februari sampai Juni 2008.

\section{Metode Pengumpulan Data}

Penelitian ini menggunakan metodologi studi kasus. Menurut Bungin (2003), secara umum studi kasus memberikan akses dan peluang yang luas kepada peneliti untuk menelaah secara mendalam, detail, intensif, dan menyeluruh terhadap unit sosial yang diteliti. Pengumpulan data biofisik, sistem agroforestri dan sosial ekonomi dilakukan dengan mengambil sampel tanah, serta melakukan wawancara mendalam dan observasi.

Pengambilan sampel tanah diambil secara purposive sampling di 3 lokasi lahan kritis terpilih berdasarkan bentuk penggunaan lahan: (1) agrisilvikultur), (2) silvopastura, dan (3) agrosilvopastura. Pada masing-masing lokasi diambil sampel tanah yang dipilih secara acak pada beberapa titik yang mewakili, lalu dikompositkan. Sampel tanah kemudian dianalisis di laboratorium dan digunakan untuk penilaian kesesuaian lahan.

Pemilihan responden yang merupakan informan kunci ditentukan secara snowball sampling, dengan ketentuan bahwa responden merupakan pemilik lahan kritis. Informan kunci dalam penelitian ini diambil 10 orang untuk masing-masing lokasi, sehingga total informan kunci adalah 30 orang. Wawancara mendalam dilakukan dengan mengadopsi diagnosis tool yang dikembangkan oleh World Agroforestry Centre (ICRAF) dan disesuaikan dengan data yang dibutuhkan untuk tujuan penelitian. Data ini diambil untuk analisis sistem agroforestri dan analisis sosial ekonomi.

\section{Analisis Data}

Analisis data yang digunakan untuk menghasilkan desain agroforestri pada lahan kritis, yaitu: analisis deskriptif, analisis kesesuaian lahan, analisis finansial (Tabel 1).

\section{HASIL DAN PEMBAHASAN}

\section{Kondisi Lahan Kritis}

Hasil pengamatan terhadap kriteria tingkat kekritisan lahan di Kecamatan Indrapuri berdasarkan kriteria yang telah ditetapkan Dirjen RRL No. 041/Kpts/V/1998 Departemen Kehutanan tahun 1998 disajikan pada Tabel 2.

\section{Sistem Agroforesti pada Lahan Kritis}

Berdasarkan komponen penyusunnya, terdapat tiga bentuk agroforestri pada lahan kritis di lokasi pengamatan, yaitu: agrisilvikultur, silvopastura dan agrosilvopastura. 
Table 1. Data Analysis

\begin{tabular}{|c|c|}
\hline Data & Data analysis \\
\hline $\begin{array}{l}\text { Identifikasi lahan kritis: } \\
\text { produktivitas, lereng, erosi, batu-batuan dan } \\
\text { manajemen }\end{array}$ & Bobot/ skoring berdasarkan Departemen Kehutanan \\
\hline $\begin{array}{l}\text { Model agroforestri yang telah ada: } \\
\text { jenis tanaman, sistem usahatani }\end{array}$ & Analisis deskriptif \\
\hline $\begin{array}{l}\text { Kesesuaian lahan: } \\
\text { temperatur, ketersediaan air, ketersediaan } \\
\text { oksigen, media perakaran, toksisitas, bahaya erosi } \\
\text { penggunaan lahan, jenis tanaman yang diusahakan }\end{array}$ & $\begin{array}{l}\text { Kesesuaian lahan Atlas Format procedures FAO dan } \\
\text { kriteria kesesuaian lahan } \\
\text { BALITBANGTANAK, } 2003 \text {. }\end{array}$ \\
\hline $\begin{array}{l}\text { Ekonomi: } \\
\text { produksi usaha, biaya usaha tani dan pendapatan } \\
\text { petani }\end{array}$ & Analisis finansial \\
\hline $\begin{array}{l}\text { Sosial: } \\
\text { tenaga kerja,status lahan, modal, sarana, } \\
\text { kebutuhan rumahtangga, dsb }\end{array}$ & Analisis deskriptif \\
\hline
\end{tabular}

Tabel 2. Land critical level based on criteria from Dirjen RRL No. 041/Kpts/V/1998

\begin{tabular}{|c|c|c|c|c|c|c|c|}
\hline \multirow[b]{2}{*}{$\begin{array}{c}\text { Observation location } \\
\text { Nillages }\end{array}$} & \multicolumn{5}{|c|}{ Criteria (\%) } & \multirow[b]{2}{*}{$\begin{array}{l}\text { Total } \\
\text { Score }\end{array}$} & \multirow[b]{2}{*}{ Critical leve } \\
\hline & $\begin{array}{l}\text { Productivity } \\
\text { (30) }\end{array}$ & $\begin{array}{l}\text { Slope } \\
(20)\end{array}$ & $\begin{array}{l}\text { Erosion } \\
(15)\end{array}$ & $\begin{array}{c}\text { Amethyst } \\
\text { (5) }\end{array}$ & $\begin{array}{l}\text { Management } \\
(30)\end{array}$ & & \\
\hline Ds.Anuek Gle & 1 & 4 & 3 & 1 & 3 & 250 & Kritis \\
\hline Ds.Reukih Dayah & 1 & 4 & 3 & 1 & 3 & 250 & Kritis \\
\hline Ds.Kreung Lamkareung & 1 & 4 & 4 & 3 & 3 & 275 & Kritis \\
\hline
\end{tabular}

\section{Agrisilvikultur}

Pada bentuk penggunaan lahan dengan sistem agrisilvikultur, petani mengkombinasikan tanaman berkayu dengan tanaman tahunan dan semusim berdasarkan landscape-nya, dengan tujuan untuk konservasi dan ekonomi (Tabel 3).

\section{Silvopastura}

Sistem silvopastura di lokasi penelitian masih sangat sederhana (tradisional), di mana lahan penggembalaan umumnya dipagari dengan pohon kuda-kuda (Spondias dulce) dan pohon Gamal (Gliricidia sephium). Tanaman tersebut merupakan komponen tanaman kehutanan yang dijadikan pakan ternak. Penanaman tanaman berkayu pada lokasi-lokasi tertentu juga ditujukan untuk tempat ternak berteduh. Pakan ternak dari jenis rumput masih kurang dibudidayakan, karena petani masih berharap dari rumput liar yang tumbuh di padang penggembalaan. Selain itu penanaman pakan ternak seperti jenis rumput gajah (Elephant grass) membutuhkan input pupuk yang tinggi untuk budidayanya.

Table 3. Component of agrisilviculture system based on landscape

\begin{tabular}{rlll}
\hline No. & \multicolumn{1}{c}{ Components } & \multicolumn{1}{c}{ Position } & \multicolumn{1}{c}{ Purposes } \\
\hline & Tanaman Berkayu & Punggung, lereng & Konservasi \\
1. & Mahoni (Swietennia sp) & Punggung, lereng & Konservasi \\
2. & Jati (Tectona grandis) & Lereng, lembah & Ekonomi/konservasi \\
3. & Rambutan (Nephelium lappaceum) & Lereng, lembah & Ekonomi/konservasi \\
4. & Pinang (Areca catechu) & Punggung, lereng & Ekonomi/konservasi \\
5. & Nangka (Artocarpus integra) & & \\
\hline & Tanaman Tahunan & Punggung, lereng & Ekonomi \\
\hline 1. & Pisang (Musa pudeca) & Lereng, lembah & Ekonomi \\
\hline & Tanaman Semusim & Lereng, lembah & Ekonomi \\
1. & Jagung (Zea mays $L$ ) & & \\
2. & Cabai (Capsicum annum) & & \\
\hline
\end{tabular}




\section{Agrosilvopastura}

Pada bentuk penggunaan lahan dengan sistem agrosilvopastura, petani mengkombinasikan tanaman berkayu dengan tanaman tahunan, tanaman semusim, tanaman pakan ternak, serta ternak berdasarkan landscape-nya, dengan tujuan untuk konservasi dan ekonomi (Tabel 4).

\section{Evaluasi Kesesuaian Lahan Agroforestri}

Evaluasi kesesuaian lahan untuk jenis tanaman yang penggunaan lahannya berbentuk agrisilvikultur diperoleh hasil tingkat kesesuaian untuk komponen tanaman berkayu dan tanaman tahunan tergolong cukup sesuai (S2), dimana yang menjadi faktor pembatas untuk tanaman jenis jati (Tectona grandis) dan pisang (Musa pedica) yaitu bahaya erosi dan penyiapan lahan karena banyaknya singkapan batu di permukaan tanah. Untuk pohon mahoni (Swietennia $s p$ ) faktor pembatas yaitu bahaya erosi. Pohon nangka (Artocarpus integra) dengan faktor pembatas yaitu retensi hara, bahaya erosi dan penyiapan lahan. Rambutan (Nephelium lappaceum) yang menjadi faktor pembatas yaitu ketersediaan air, retensi hara, bahaya erosi dan penyiapan lahan. Pinang (Areca catechu) yang menjadi faktor pembatas yaitu ketersediaan air dan bahaya erosi. Faktor pembatas untuk tingkat S2 seperti retensi hara dapat diperbaiki dengan pemberian input pupuk, pengapuran, pengolahan tanah atau sebagainya yang biasanya dapat diatasi oleh petani. Sedangkan untuk tanaman semusim yaitu jagung (Zea mays) dan cabai merah (Capsicum annum) tingkat kesesuaiannya tergolong sesuai marjinal (S3), dimana faktor pembatasnya yaitu ketersediaan air.

Sistem silvopastura diperoleh hasil tingkat kesesuaian tanaman berkayu jati dan mahoni tergolong cukup sesuai (S2). Tanaman tahunan yaitu pisang tingkat kesesuaian lahan tergolong cukup sesuai (S2) dan untuk tanaman pakan ternak jenis rumput gajah memiliki tingkat kesesuaian lahan sesuai marjinal (S3).

Hasil evaluasi kesesuaian lahan untuk jenis tanaman yang penggunaan lahannya berbentuk agrosilvopastura diperoleh hasil untuk komponen tanaman berkayu jati (Tectona grandis), mahoni(Swietennia sp), kemiri (Aleuritas moluccana), memiliki tingkat kesesuaian lahan tergolong cukup sesuai (S2); sedangkan mangga (Mangifera indica), nangka (Artocarpus integra), rambutan (Nephelium lappaceum), pinang (Areca catechu) memiliki tingkat kesesuaian lahan tergolong sesuai marjinal (S3). Selanjutnya tanaman tahunan pisang (Musa pudeca) dan kakao (Theobroma cacao $L$ ) dan pakan ternak rumput gajah (Pennisetum purpureum), memiliki tingkat kesesuaian lahan tergolong sesuai marjinal (S3).

Table 4. Components of agrosilvopasture system based on landscape

\begin{tabular}{rlll}
\hline No. Components & \multicolumn{1}{c}{ Position } & Purposes \\
\hline 1. & Tanaman Berkayu & Punggung, lereng & Konservasi \\
2. & Jati (Tectona grandis) & Punggung, lereng & Konservasi \\
3. & Kemiri (Aleuritas moluccana) & Lereng & Ekonomi/konservasi \\
4. & Mangga (Mangifera indica) & Lereng & Ekonomi/konservasi \\
5. & Nangka (Artocarpus integra) & Lereng & Ekonomi/konservasi \\
6. & Rambutan (Nephelium lappaceum) & Lereng, lembah & Ekonomi/konservasi \\
7. & Pinang (Areca catechu) & Punggung, lereng & Ekonomi/konservasi \\
\hline & Tanaman Tahunan & & \\
1. & Pisang (Musa pudeca) & Punggung, lereng & Ekonomi \\
2. & Kakao (Theobroma cacao L) & Lereng & Ekonomi \\
\hline & Tanaman Semusim & & \\
1. & Cabai (Capsicum annum) & Lembah & Ekonomi \\
2. & Terung (Solanum melongena) & Lembah & Ekonomi \\
\hline & Tanaman Pakan Ternak & & \\
1. & Rumput Gajah (Pennisetum purpureum) & Lereng, lembah & Ekonomi/konservasi \\
\hline & Ternak & & \\
1. Sapi (Bos taurus sp) & Punggung,lereng & Ekonomi \\
2. & Itik (Anas plathyrhynchos) & Lembah & Ekonomi \\
\hline
\end{tabular}


Table 5. Financial analysis of agroforestry system per hectar at Indrapuri Subdistrict

\begin{tabular}{|c|c|c|c|}
\hline Criteria & Agrisilviculture & Silvopasture & Agrisilvopasture \\
\hline NPV & Rp. 55.374.410,- & Rp.84.111.784,- & Rp.147.896.794,-- \\
\hline BCR & 2,2 & 1,5 & 2,7 \\
\hline IRR & $31 \%$ & $38 \%$ & $46 \%$ \\
\hline
\end{tabular}

\section{Analisis Finansial}

Analisis finansial terhadap sistem agroforestri di Kecamatan Indrapuri dengan jangka waktu pengusahaan 20 tahun dan tingkat suku bunga $8 \%$, di peroleh, nilai NPV > 0 (positif), dan B/C Ratio $\geq 1$ dan nilai $I R R \geq$ tingkat suku bunga (i) untuk semua bentuk penggunaan lahan (Tabel 5). Hal ini menunjukkan bahwa semua sistem agroforestri baik yang berbentuk agrisilvikultur, silvopastura maupun agrisilvopastura layak untuk dilaksanakan.

\section{Desain Agroforestri Pada Lahan Kritis}

Untuk mengadopsi teknologi kegiatan usaha tani perlu diketahui kendala spesifik yang ada di lokasi tersebut. Faktor penghambat itu sendiri, ada yang dapat dimanipulasi atau diperbaiki dengan teknologi, akan tetapi ada juga faktor penghambat yang sulit diperbaiki karena akan membutuhkan biaya yang tinggi dan sulit diperbaiki oleh petani. Untuk itu diperlukan bantuan dari pihak terkait untuk membantu petani di dalam pengelolaannya. Pada Tabel 6 menunjukkan kendala yang ada di lokasi penelitan dan teknologi yang memungkinkan untuk di adopsi di dalam kegiatan usaha tani.

Berdasarkan hasil evaluasi kesesuaian lahan maka direkomendasikan jenis tanaman berkayu Non MPTs adalah jati dan mahoni karena tergolong cukup sesuai (S2), untuk tanaman MPTs seperti rambutan, nangka, mangga, pinang dan kemiri pada daerah tertentu tergolong sesuai marginal (S3), akan tetapi dengan pemberian pupuk dapat ditingkatkan menjadi cukup sesuai (S2). Demikian juga halnya untuk tanaman tahunan seperti pisang dan kakao dengan pemberian pupuk dapat ditingkatkan kesesuaiannya menjadi cukup sesuai (S2). Untuk tanaman semusim seperti cabai, terung dan jagung, tergolong (S3) atau sesuai marginal, ini tentu saja membutuhkan input pupuk yang cukup tinggi dalam membudidayakannya.

Berdasarkan pengamatan dan wawancara, diperoleh profil komponen penyusun sistem agroforestri pada lahan kritis menurut landscape seperti terlihat pada Gambar 1. Tanaman berkayu seperti jati dan mahoni akan lebih baik ditanam pada daerah punggung bukit, karena lebih adopted pada kondisi lahan yang ekstrim. Tanaman MPTs, tanaman tahunan dan pakan ternak lebih baik ditanam pada bahagian lereng dan lembah, dengan asumsi bahwa tingkat kesuburannya lebih baik daripada di bahagian punggung bukit. Keberhasilan agroforestri berbasis pohon salah satunya didasarkan pada pemilihan jenis. Prinsip pemilihan jenis pohon dalam agroforestri adalah ketepatan antara lokasi pemapanan dengan karakteristik jenis terpilih serta nilai peruntukanya (Suryanto et al, 2005).

Table 6. Constraint and technology input alternative

\begin{tabular}{|c|c|c|}
\hline No. & Constraint & Technology input \\
\hline 1. & Ketiadaan dana untuk modal & $\begin{array}{l}\text { Kebijakan pemerintah dalam pemanfaatan lahan } \\
\text { kritis dan bantuan kredit lunak. }\end{array}$ \\
\hline 2. & Kesuburan tanah rendah & Penanaman tanaman berkayu dan pemulsaan \\
\hline 3. & Rendahnya serasah & Pemupukan dan pemulsaan \\
\hline 4. & Curah hujan musiman yang tidak mencukupi & $\begin{array}{l}\text { Penanaman tanaman berkayu dan pembuatan } \\
\text { sumur/sumur resapan }\end{array}$ \\
\hline 5. & Banyaknya batuan & Pengolahan tanah \\
\hline 6. & Rendahnya mutu makanan ternak & $\begin{array}{l}\text { Penanaman rumput pakan ternak yang tahan } \\
\text { terhadap kondisi lahan kritis }\end{array}$ \\
\hline
\end{tabular}




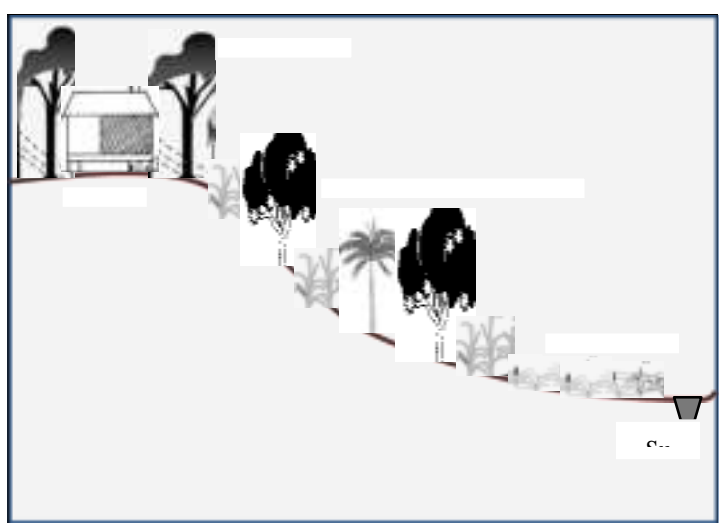

Figure 1. Component profile of agroforestry system at critical land

Selanjutnya diketahui bahwa air menjadi permasalahan tersendiri bagi petani, oleh karena itu disarankan agar pada bahagian lembah dari kebun dilakukan pembuatan sumur atau sumur resapan agar pada musim panas ketersedian air mencukupi untuk kebutuhan usahatani. Adapun desain agroforestri pada lahan kritis menurut landscape dapat dilihat pada Gambar 2.

\section{KESIMPULAN DAN SARAN}

\section{Kesimpulan}

1. Berdasarkan komponen penyusunnya terdapat tiga sistem agroforestri yang dilakukan oleh masyarakat pada lahan-lahan kritis, yaitu berbentuk agrisilvikultur, silvopastura dan agrosilvopastura, dimana sistem agroforestri yang ada merupakan sistem agroforestri tradisional yang dikelola menurut kondisi dan kearifan lokal.

2. Lahan di lokasi penelitian tergolong kritis, dan berdasarkan evaluasi kesesuaian lahan terhadap jenis tanaman yang ada di kebun, diperoleh tingkat kesesuaian untuk komponen tanaman berkayu dan tanaman tahunan tergolong cukup sesuai (S2) dan komponen tanaman semusim tergolong sesuai marginal (S3). Analisis finansial menunjukkan bahwa secara ekonomi ketiga sistem agroforestri di lokasi penelitian layak untuk dilaksanakan.

3. Desain agroforestri pada lahan kritis menurut landscape, direkomendasikan untuk jenis tanaman berkayu, jenis NonMPTs lebih adopted di daerah punggung

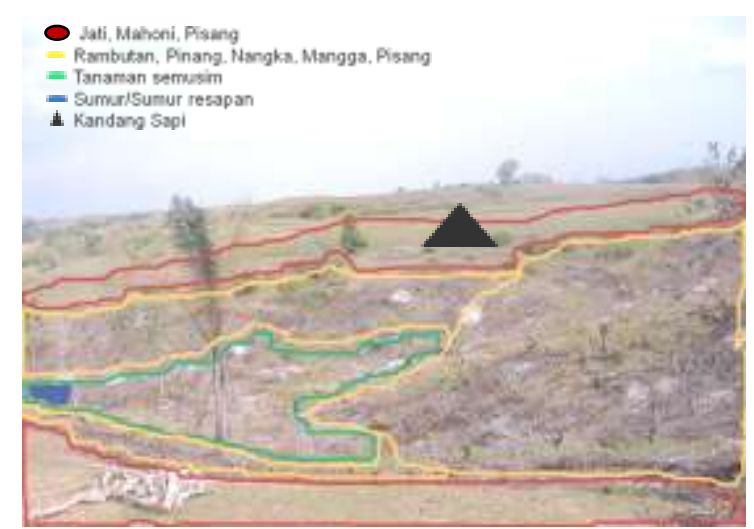

Figure 2. Agroforestry design at critical land based on landscape

bukit, tanaman MPTs dan tanaman tahunan lebih diarahkan pada daerah lereng dan lembah, sedangkan untuk tanaman semusim/palawija lebih baik ditanam pada bahagian lembah.

\section{Saran}

1. Pemanfaatan lahan kritis untuk kegiatan usaha tani yang dilakukan oleh masyarakat, merupakan suatu hal yang positif yang harus digalakkan dan didukung oleh pemerintah daerah, dalam bentuk program-program rehabilitasi lahan kritis dengan sistem agroforestri.

2. Sistem agroforestri tradisional yang selama ini dilakukan oleh masyarakat, harus terus dipertahankan dengan perbaikan teknologi, juga memperhatikan kaidah-kaidah konservasi.

3. Untuk mengantisipasi kebutuhan air pada musim panas dilakukan pembuatan sumur/sumur resapan pada bagian lembah.

4. Perlu dilakukan penelitian lanjutan terutama didalam aplikasi teori dan desain yang ada, dan melihat sejauh mana sistem dapat berjalan untuk kemudian dilakukan kajian lanjutan dalam memperbaiki sistem.

\section{DAFTAR PUSTAKA}

BPS Kabupaten Aceh Besar. 2006. Kabupaten Aceh Besar dalam Angka tahun 2006. Badan Pusat Statistik.

Bungin, B. 2003. Data Penelitian Kualitatif. PT. Raja Grafindo Persada. Jakarta. 
Departemen Kehutanan dan Perkebunan. 2002. Rehabilitasi lahan dan perhutanan sosial. (Statistik kehutanan Indonesia 2002). Htpp://www.dephut.go.id.

Direktorat RKT. 1997. Kriteria Penetapan lahan kritis. Direktorat Rehabilitasi dan Konservasi Tanah. Ditjen RRL, Departemen Kehutanan. Jakarta

Hardjowigeno dan Widiatmaka. 2001. Kesesuaian Lahan dan Perencanaan Tataguna Tanah. Jurusan Tanah Fakultas Pertanian IPB. Bogor

Lundgren, B.O. and J.B. Raintree. 1982. Suistainabed agroforetry. In: Nestel B (ed.) 1982. Agricultural Research for Development. Potentials and Challenges in Asia, ISNAR, The Hague, The Netherlands. hal 37- 49.

Diterima : 30 September 2009

\section{Bukhari}

Dinas Kehutanan Kabupaten Aceh Besar

J. Prof. A. Madjid Ibrahim, Jantho

e_mail: bukhari_wana@yahoo.co.id

Indra Gumay Febryano

Jurusan Kehutanan

Fakultas Pertanian, Universitas Lampung

Jl. Prof. Soemantri Brodjonegoro No. 1, Bandar Lampung e-mail: indragumay@yahoo.com
Suryanto, et al. 2005. Dinamika Sistem Berbagi Sumberdaya (Resources Sharing) dalam Agroforestri: Dasar Pertimbangan Penyusunan Strategi Silvikultur. IImu Pertanian Vol 12. No 2, 2005 : 165 - 178.

Van Noordwijk dan Hairiah. 2006. Agricultural Intesification, Soil Biodiversity and Agroecosistem Function. Agrivita volume 28 No 3.

Widianto, Utami dan Hairiah. 2003. Agroforestri dan ekositem Sehat. International Center for Research in Agroforestry - ICRAF Southeast Asia. Bogor, Indonesia.

Wojtkowski, P.A., 2002. Agroecological Perspectives in Agronomi, Forestry, and Agroforestry. Science Publisher, NH, USA 